\title{
Altruistic and Anomic Suicide: A Durkheimian Analysis of Palestinian Suicide Bombers
}

\author{
Reem A. Abu-Lughod ${ }^{1} \&$ Eduardo L. Montoya ${ }^{2}$ \\ ${ }^{1}$ Department of Criminal Justice, DDH-C123, California State University, Bakersfield, Bakersfield, USA \\ ${ }^{2}$ Department of Mathematics, 14-SCI, California State University, Bakersfield, Bakersfield, USA \\ Correspondence: Reem A. Abu-Lughod, Department of Criminal Justice, DDH-C123, California State University, \\ Bakersfield, 9001 Stockdale Highway, Bakersfield, CA 93311, USA. E-mail: rabu_lughod@csub.edu
}

\author{
Received: January 17, 2016 Accepted: February 20, $2016 \quad$ Online Published: May 29, 2016 \\ doi:10.5539/jpl.v9n4p30 \\ URL: http://dx.doi.org/10.5539/jpl.v9n4p30
}

\begin{abstract}
In the past two decades, suicide terrorism in its different forms has become a popular topic of research and debate. It has contributed to a different sense of normalcy and regularity in various societies across the world given that suicide bombings are relatively inexpensive and effective, compared with other kinds of terrorist methods. This study primarily focuses on suicide bombings in the Palestinian/Israeli territories, an area that has experienced conflict and tension for over six decades. In doing so, the research study uses Durkheim's typology of suicide as a theoretical framework to trace the history of suicide bombings in the Palestinian/Israeli territories, outline the characteristics of suicide bombers, their motivations, and how suicide bombings have been used as a form of resistance to occupation. The data collected cover suicide bombings that have occurred from April 1994 to February 2008. The research study uses logistic regression to examine the characteristics of the suicide bombers and their attacks. The results show, among other things, that the attacks possess elements of both altruistic and anomic types of suicide in the Durkheimian sense of the word.
\end{abstract}

Keywords: suicide bombings, terrorism, Durkheim, Intifada, occupation

\section{Introduction}

Motivations and societal factors impacting suicide rates were first examined by Emile Durkheim in his 1897 book Suicide. While Durkheim's study was considered a groundbreaking discovery in the 19th century, his contributions are still valid in modern day societies that lack stability and adherence to societal norms. Durkheim primarily argued that suicide is not necessarily an individualistic act resulting from emotional stress, but rather has its roots in the structure of society and its external factors impacting individual behaviors. In the past two decades, suicide, and in particular, suicide bombing, has become a very popular topic of research and debate, ranging in regions from the Far East, to Eastern Europe, and the Middle East. Particularly impactful have been suicide bombings among the Palestinians in the Palestinian/Israeli region. In this research study, a theoretical framework is developed to examine suicide bombing among the Palestinians using Durkheim's typology of suicide. While Durkheim focused on ordinary suicide, his theory provides a useful tool in applying it to suicide terrorism.

Various research studies (e.g. Townsend 2007; Pedahzur et al 2003; Benmelech et al 2012; Pape 2005) showed a correlation between economic conditions, altruism, and fatalism as motivations to suicide bombings among the Palestinians. This research study reemphasizes the influence of economic conditions and altruistic behavior as motivating factors to suicide bombings among the Palestinians. However, this study specifically argues that Palestinian suicide bombings, including those that have occurred during the Second Intifada (between 2000-2005), possess elements of either altruistic or anomic type of suicide in the Durkheimian sense of the word. First, the research provides a theoretical framework of Durkheim's typology of suicide, with a particular influence on the Palestinian suicide bombers. Second, the study focuses on the micro level individual vs. the macro level societal influences that impact behavior by reflecting upon prior research on political, economic, and social influences in societies. Third, the study presents a brief background of the Palestinian/Israeli conflict, with a close look at suicide bombing as an act of resistance. Fourth, the research focuses on the individual psychological dynamics, reflecting upon examples that researchers have used to examine suicide from a Durkheimian perspective. Fifth, using logistic regression and suicide bombing data from the Palestinian/Israeli 
conflict, our analysis shows that Palestinian suicide bombers possess elements of the altruistic and anomic types of suicide. Finally, the research concludes by providing a brief analysis of the results, as well as showing how suicide bombing is not a new phenomenon, rather one that has its roots in different cultures and societies, including the Western world.

\section{Durkheimian Analysis of Suicide: A Theoretical Framework}

According to Durkheim, an individual who is very strongly or very weakly integrated into society, may under certain (different) circumstances; e.g. social, political, and economic pressures, commit suicide. An individual who commits suicide because of weak societal bonds will commit what Durkheim refers to, an egoistic type of suicide. On the other hand, an individual who is very strongly integrated into society will commit an altruistic type of suicide.

The other contributing factor to suicide, in Durkheim's terms, is regulation; a form of societal control of an individual's actions and desires. Similarly to integration, excessive regulation or rather the lack thereof, will likely increase suicide rates. Suicide that results from low levels of regulation is referred to as anomic suicide. Crises, such as the one demonstrated by the Palestinian/Israeli conflict, are only one of many examples that reflect this type of suicide. On the other hand, a fatalistic type of suicide occurs among individuals that are highly regulated by society; those whose future has been violently blocked by an oppressive power.

With respect to the Palestinian suicide bombers, their belongingness to a group (e.g. Hamas) exerts an excess of social integration, and are therefore altruistic (as opposed to egoistic, which argues a lack of social integration and weak group membership) (Leenaars \& Wenckstern 2004).

The burden that the Palestinian suicide bombers believe their society places on them to sacrifice their life for the majority compels them to commit the act of suicide in hopes that it will cause change (Pape 2003). While the micro-level individual (or suicide bomber in this case) does not see the immediate change in society (since their death is certain in the act), it is the interest of the collective society at the macro-level that is held in higher regard than that of the individual suicide bomber, who views his life as secondary (Johnson 1979).

Suicide attacks are quite a unique phenomenon, and are different from "terrorist" attacks. For example, "terrorist attacks" involve some sort of intimidation, fear and various tactics implemented to cause the maximum amount of damage. Suicide attacks, on the other hand, are different in a sense that the individual carrying out the attack knows that he/she will die in the act. A suicide attack is therefore an "operational method in which the very act of the attack is dependent upon the death of the perpetrator" (Ganor 2000:1). Furthermore, a suicide attack compared with other types of so-called terrorist activities, "is a simple and low-cost operation, it guarantees mass casualties and extensive damage; there is no fear that the interrogated terrorists will surrender important information; and it has an immense impact on the public and the media" (Sprinzak 2000: 66-8).

It is important to note that the unemployed, unmarried, or young Palestinian suicide bomber is unlikely to commit the act of "suicide" without the help and support of the organization within which he belongs (Moghadam 2002; Atran 2003; Rosenberger 2003). Also, while the leaders of the organization do not necessarily volunteer to commit the act of "suicide," this shows a definite distinction between what the individual suicide bomber hopes to gain versus what the organization hopes to accomplish (Moghadam 2002; Poland 2002). In both aspects, however, Palestinian nationalism and the creation of an independent State is seemingly the ultimate goal among the Palestinian suicide bombers. However, the drive to accomplishing it and the belief behind the rewards of sacrificing one's soul, differ between the micro level individual and the macro level organization. This shows the perpetrator's strong integration and commitment to the "group" as a whole.

There is also no doubt that economic deprivation contributes to distress, leading an individual to commit acts that may deviate from the societal norms, and therefore be characterized as anomic (Krueger \& Malechova 2003). For example, according to the International humanitarian law and the human rights law, the State of Israel is required to grant Palestinians in the Occupied Territories a right to work and have adequate livelihood (see Khawaja 1995; Roy 2001). However, Palestinians have been denied those rights and have rather been exploited by their employers (Roy 2001). Furthermore, the divide between the Palestinian and Israeli territories have made movement between the borders more stringent, creating an additional barrier to Palestinians in the occupied territories to pursue work, adequate healthcare and even schooling (OXPIL 2004). As a result of that and other political pressures, social repression, and a lack of an established independent State of Palestine, the Palestinians experienced economic hardship among their population.

Most of the financial support from Israel aimed at granting work to Palestinians was dependent on Palestinian workers being integrated into the Israeli workforce, particularly between 1967-1993 (the time leading to the 
outbreak and "conclusion" of the First Intifada) (Kadman 2012). However, with the establishment of a Palestinian Authority in 1994 along with the outbreak of the Second Intifada in 2000, political struggles against the Israeli occupation and violent attacks witnessed from both the Palestinians and Israelis have created harsher restrictions on Palestinians moving within and from the Occupied Territories, as well as cutting funds and resources received by the Palestinian Authority (Brym \& Araj 2006).

Surprisingly, much of the empirical research vested in the study of terrorism did not necessarily find a direct correlation between poverty/economic conditions and suicide attacks (Abadie 2006; Krueger \& Laitin 2008; Krueger \& Malechova 2003). However, while a direct connection between lower socioeconomic status and terrorism may somewhat be lacking, it is imperative to note that economic conditions, or rather hardships, impact the type of terrorist attacks committed (Benmelech et al 2012).

For instance, Bueno de Mesquita (2005a) examines how economic conditions correlate with the quality rather than the quantity of terrorism in general. He suggests that there is a direct correlation between good economic conditions as well as low rates of unemployment and an individual's decision to join a terrorist organization, committing terrorist related activities. Following the Durkheimian perspective, we view suicide attacks that occurred during economic deprivation and hardships as the anomic type.

The Second Intifada may be viewed as a time of economic deprivation and hardship compared with the First Intifada (Moghadam 2003); when economic conditions were relatively better and Palestinians had access to jobs, with little reason to commit suicide attacks (Roy 2001). To further emphasize this, the data we use in this research study consist of suicide attacks that occurred between 1994 and 2008, to investigate whether the attacks during the Second Intifada were more likely to possess elements of the anomic type.

While the Intifada has contributed to suicide bombings among the Palestinians in terms of political resistance, other social institutions in society also play a role in impacting the micro level individual behavior. The following sections examine the significance of how social institutions such as religion, the structure of society and economic status, all affect deviance in different levels and intensities.

\section{Social Institutions: The Micro vs. Macro Level Influence}

There is no doubt that the individual's psychopathology may be a motivating factor to committing suicide. Durkheim, though, places more emphasis on how society impacts individuals' behavior, driving them toward, or away from suicide. Durkheim examines social institutions (e.g. marriage, religion, the economy, and politics) to show the interaction between them and the "suicidal" individual.

Pape, in his study and data compilation of suicide terrorism, presents that "suicide terrorism is not overwhelmingly a religious phenomenon" (2005:210). He argues that suicide terrorism "is an extreme strategy for national liberation" under three conditions: first, when a "national community is occupied by a foreign government; second, when that occupier is of a different religion to the terrorist group and the community it purports to represent; and third, when the foreign power is a democracy (2005:80). However, Pape also argues that religion is the primary construction of nationality, and so this religious nationalism explains the extreme response of suicide terrorism under foreign occupation (2005:87-88).

Though some research studies have associated the Palestinian suicide attacks with Islamic fundamentalism, there is little evidence to support that "religion" is the sole driving force. Furthermore, Islam forbids suicide and punishes those who have committed the act (Abdel-Khalek 2004; Taylor \& Ryan 1988). Since the lack of strong religious beliefs may prompt an individual to commit suicide (Nonnemaker et al, 2003), other research studies have shown a link between strong religious beliefs and affiliations particularly among those who believe in the benefits of the afterlife (Abdel-Khalek 2004). While the religious component should not be discarded, it is important to note that, among the Palestinian suicide bombers, societal and political pressures are more significant in impacting the motivation behind a suicidal attack (Pape 2003; Merari 2005; Sprinzak 2000).

Furthermore, history shows that suicide attacks, in their different forms, have been carried out by different religious groups; Hindus, Christians, and Jews as well. Therefore, to argue that Islam condones suicide bombings and that the Sharia Law promises the Shaheed (martyr) 72 virgins is a one-sided view (Munir 2008). In addition to that, there has been a lack of consensus among Islamic scholars on the legitimacy behind suicide attacks against the Israelis. Most of the Fatwas given have simply been relative interpretations of the Quran and Hadith; records of sayings and actions of the Prophet Muhammad (Paz 2000).

Making religion the motive behind suicide bombings among the Palestinians is therefore too simplistic. It shows that the Palestinians are fanatics, which this paper argues that they are not. Also, if strong Islamic beliefs are the sole motivating factors behind the attacks, then perhaps secular terrorist organizations, such as Fatah, would not 
be carrying out such acts (Pape 2003; Moghadam 2002). It is arguably a combination of social, economic, and political conditions, along with a strong belief of the legitimacy of the cause (Brym \& Araj 2006) that make suicide bombing a commitment pressuring the micro-level individual to carry out the act. In fact, it is a person with little religious commitment and perhaps a strong political ideology, who is more likely to take one's self in exchange for the unknown (Post el al 2003). To overcome the stigma of "suicide," suicide bombers are often referred to, by radical supporters, as Shaheed in contrast to those who simply commit suicide (intihar) without commitment to a cause. As some believers may argue, the act of martyrdom is a form of self-sacrifice to serve Allah and promote change, while intihar is a reflection of weakness and selfishness (Post et al 2003).

Two organizations, namely Hamas and Palestinian Islamic Jihad (PIJ), have historically recruited religious Palestinians and excluded seculars who may be willing to become Shaheeds. Following 2002, most suicide bombers belonged to Fatah, a Palestinian group whose political ideology is largely secular (Moghadam 2002). $\mathrm{Be}$ it religious, economic or even political, it would be significant to note that these factors combined, in different intensities and depending on the personality of the individual, are driven by altruistic as well as anomic types of suicide. This explains why the individual commitment to the group outweighs the value that the individual "suicide bomber" places upon himself/herself (Atran 2003; Post el al 2003). As the altruistic nature of suicide becomes more prominent, the Palestinian suicide bomber in this case becomes engulfed in the cause/goal that he is fighting for: Palestinian Nationalism (Merari 1998; Merari 2005; Post el at 2003). As a result, the benefit that the suicide bomber sees upon his society and his belief of the afterlife outweighs the benefit of his current status in life.

Despite that, religion, though not the sole component, is still considered important, as the individual "martyr" (as some would argue) has strong beliefs of the religious legitimacy of the act as explained by the leader of the organization (Abdel-Khalek 2004). To reiterate, suicide bombing has been largely associated with individuals who belong to a radical Islamist group or a radical secular group that justify the act as martyrdom rather than suicide; where the individual suicide bomber receives an honorary funeral for the former and punishment by God in the latter (Hassan 2001; Orbach 2004).

As a result, the suicide bombers, or as their society may perceive them, freedom fighters, become, as Sheikh Muhammad Hussein Fadlallah (the former spiritual leader of Hizballah), once stated "...not preachers of violence... Jihad in Islam is a defensive movement against those who impose violence" (Hoffman, 1998).

The Shaheed finally proves his act by showing his heroic behavior against the cowardice society he is fighting against. According to Israeli counterterrorism expert, Reuven Paz, the martyrs must prove to the enemy "that they are truly brave, because the ultimate bravery and heroism lie in seeking out death, thus showing the enemy as cowards and themselves as heroes" (Paz, p. 93). The little hope that the suicide bomber possesses in his current life (showing signs of the anomic type of suicide) is countered by his hopefulness of what he is promised in the afterlife (Williams 1997); e.g. marriage to 72 huris, security from hell, and other privileges that he can never attain in the life he already has (Hassan 2001).

While the above examined social institutions, along with political influence and societal pressures all show an influence on the Palestinian suicide bomber, it is imperative to provide a brief historical overview of the Palestinian/Israeli conflict with a primary focus on the first and second Intifadas, both as possible explanations to suicide bombings.

\section{The Palestinian/Israeli Conflict: Continued Tension, Struggle and Resistance}

For over six decades, the Palestinian/Israeli conflict has continued to infuse more violence in the region. Attempted peace processes have ironically only contributed to revenge and conflict over territory and boundaries, leading to further divide the Israelis and Palestinians (Moghadam 2003). Furthermore, the Separation Wall between the two has physically contributed to distance both groups and create more hostility, particularly from the Palestinians, who view the "wall" as the Apartheid Wall. As a result, the region has experienced volatile violence in response to different social, political (Reich 1990), and economic pressures (Gurr 1970; Moore 2003).

Atra (2006) makes a very significant point in his study of suicide terrorists. He states that during the 1990's, momentous political developments in Algeria (multiparty elections, including Islamic groups in 1992), Palestine (Oslo Peace Accords in 1993), Chechneya (dissolution of the Soviet Union and the end of Communist control), Indonesia (Suharto's resignation in 1999 and the end of dictatorship), and elsewhere around the world, have fanned uprisings.

Pedahzur et al. (2003) also point out that societies with excessive social regulation, poor opportunities for 
individual socio-economic mobility, an oppressive government, and high social cohesion and internalization of the social group's values and goals are more likely to support suicide terrorism (2003:421). They further emphasize that suicide bombers are not necessarily uneducated young males controlled by the leadership of an organization. Rather they argue that:

The atmosphere in the Gaza strip and on the West Bank is such that the would-be martyr's decision to embark on his journey is in fact reinforced by the approval of the community in a society where honor is among the highest virtues, there are indeed powerful social pressures lying behind the suicide bomber's decision (2003:420).

Conflict between the Israelis and Palestinians has been particularly heightened during the first and second Intifadas; a form of Palestinian uprising against Israeli military occupation (Kadman 2012). Whether it was an incident of a truck bombing that left several Palestinians dead in 1987 or demonstrations against the Israeli Defense Forces and the death of 6 Israeli soldiers, the first Intifada, which took place roughly between 1987-1993 was arguably a resistance movement to Israeli rule of the occupied territories (Roy 2001). It was further intensified by the Palestinians' frustrations to the loss of hope in establishing an independent Palestinian state. The Palestinians used tactics such as throwing stones and Molotov Cocktails at Israeli forces. In response, the Israeli military enforced curfews and other forms of control upon the Palestinians (Fischer et al 2001). It was only until the signing of the Oslo peace accords in 1993 that the Palestine Liberation Organization (PLO) agreed to recognize the State of Israel in exchange for Israeli recognition of the PLO as the representative of the Palestinians (Roy 2001). The Oslo Accords further contributed to the creation of the Palestinian authority, giving them partial governance power over part of the Occupied Palestinian Territories.

Prior to the first Intifada, and more precisely following the 1967 Six Day War coupled with frustrations among the Palestinians, Israel recruited many Palestinians to work in unskilled and/or semi-skilled labor jobs. However, with an increase in birth rates among the Palestinians, and a growth in population density in addition to a rising rate of unemployment, a lack of achievement and productivity particularly among those with university degrees became evident (OXPIL 2004). As a result, the situation between the Palestinians and Israelis never quite settled. If anything, it continued to raise more issues of conflict and struggle (Kadman 2012).

With continued insecurity in the region, lives lost among both the Palestinians and Israelis, and peace seemingly out of reach between the two, suicide bombings proved to be lethal, sending a message that the Palestinians are resilient and are willing to sacrifice their lives for the Palestinian cause (Brym \& Araj 2006).

Though the first notable suicide bombing did not take place until 1993, since the Israeli occupation and the establishment of an independent State of Israel in 1948, the Palestinians' motivation to sacrifice their lives in hopes for nationalism and independence has strengthened (Abadie 2006). The past six decades have therefore been tensional between the Israelis and the Palestinians. With attempted negotiations and failed strategies to establish peace, the Palestinians became more persistent about gaining territory and establishing Palestinian Nationhood. Therefore, the Palestinians' strategy in using suicide bombings became a weapon to instill fear in the Israeli region (Pape 2003). Suicide bombers were also used to cause the maximum amount of damage among the Israeli population. This rebellious fight against Israeli authority became, as Friedland notes, an insurgent type of terrorism (Friedland, 1992)

The late 1990s remained a time of resolving conflict and negotiating some sort of settlement between the Palestinians and Israelis. However, by September 2000, the Second Intifada erupted between the two. There have been many contentions on what may have triggered the second Intifada. While some Palestinians blame it on Ariel Sharon's (Israel's late and former Prime Minister) visit to the Temple Mount, others say that it was a result of failed negotiations at the Camp David Summit in July 2000; which were directed at ending the Palestinian/Israeli conflict. An agreement was never reached between former U.S. President Bill Clinton, former Israeli Prime Minister Ehud Barak, and the late Palestinian Authority Chairman Yasser Arafat, further distancing any peace movements between the two parties (Fischer 2001).

During the Second Intifada, suicide bombings were used more extensively by the Palestinians in response to Israeli military forces (Roy 2001). However, as the separation wall became more prominent and extended the divide between the Israelis and Palestinians, there was a noted decrease in suicide attacks (Israeli Ministry of Defense, 2006). Mainly through a physical restraint, the decrease only temporarily muted the suicide attacks but did not necessarily stop the motivation behind committing those acts. Many have attributed the decrease in suicide bombings to various factors (Friedland 1992). On one hand, Israel was credited for its intelligence tactics that were used to stop the attacks before they occurred; partly because of its enhanced security in the region, and in another part due to its military campaign against terrorism. Israel's tactic of assassinations and arrests of so-called "wanted" terrorists though fueled the Palestinians with anger, thus continuing the cycle of violence, 
committing suicide bombings whenever and wherever possible (Roy 2001).

Hence, the struggle between the Palestinians and Israelis, in addition to the establishment of an Independent State of Israel have triggered conflict and violence at the macro level, not only between the Palestinians and Israelis, but also between the Arabs and Israelis as a whole. The Israeli military occupation is therefore perceived to be the driving political force in instigating violence against occupation of "stateless" Palestine. While the politics of the Palestinian/Israeli conflict remain an important factor to examine, it is also significant that one also looks at the inter as well as the intrapersonal dynamics that promote violence.

\section{A Psychological Dilemma: A Tool of Resistance?}

Suicide bombings among the Palestinians have become a psychological weapon used to lower morale among the Israeli society. The attacks were used to reemphasize that the Palestinians will not give in or compromise on territory and land; keeping their "right of return" alive (Pape 2003, 2005). From a psychological perspective, researchers have placed the blame on the individual for committing suicide. While the intrapersonal dynamics play an important role in impacting behavior, one cannot overlook the differences in personality components, educational levels, financial stability and other factors that differ from one person to another. Furthermore, while the psychological component cannot be ignored or even overlooked, it also cannot be the sole explanation to deviance from societal norms.

To argue that suicide bombers are irrational and experience some sort of psychopathology (Le Bon 1969 [1895]) different than that of the general population, defies the very purpose that they are fighting for. While suicide bombers may be viewed as fatalistic in their expression of behavior, they are indeed rational in justifying why they commit suicide. As a result, "suicide" among the Palestinians becomes a form of resistance and protest used to enhance their ideology and send their message to society and their sovereign and oppressive authoritative power.

Sacrificing one's life in the interest of society, as the one seen among the Palestinians, is common among different cultures. It is the sense of belongingness and attachment to the cause that has propelled Palestinian men and women to commit acts of suicide bombings (Abdel-Khalek 2004). Among the Danish community, dying of sickness and old age may deny the person funeral honors. It is therefore the burden, shame and humiliation from society that the old, sick Danish man and widowed Hindu woman "... who climbs on the funeral pyre to be with her husband forever" (Leenaars \& Wenckstern 2004, p.131), cannot bear and would rather destroy themselves. Those societal values are deemed very strong and place a strong sense of bonding and attachment upon the individual, making that individual's personality weaker than the individual's strong sense of attachment to his/her community and culture (Johnson 1979). This strong absorption into community and cultural rules slowly diminishes the individuation itself. At a micro level, the individual thus becomes overwhelmed with the macro level societal pressures, which are believed to be more cohesive than the micro level individual (Young 1972).

As the ideology of the individual becomes stronger, little value is placed on the individual life, and greater value is placed on the cause and the aftermath of suicide (Pedahzur et al 2003). The Palestinian martyr's status is elevated after his Istishhad (martyrdom), bringing honor to his funeral and family and glorifying his death as one that is highly treasured. Furthermore, the dignity that the Shaheed believes he gains far outweighs the humiliation of living under occupation. This, as a result, makes the volunteer for martyrdom more motivated to commit the act of suicide bombing (Hassan 2001; Post et al 2003).

While this type of suicide is largely a consequence of the strong sense of belonging, attachment and commitment to the group, this paper reemphasizes that it is possesses a strong sense of altruistic suicide that is taking place among the Palestinian suicide bombers (p.221). As Spaulding and Simpson (1979) present, not every altruistic suicide is necessarily obligatory in a sense. To further illustrate, while the Palestinians do not necessarily have a specific spoken or written rule by the group to commit suicide, there also isn't an unspoken or unwritten rule stopping them from doing so. Therefore, while death under these circumstances is not denounced, it is often praised with prestige, courage, honor and value attached to the self.

Moreover, while an altruistic type of suicide may not be seen as a direct duty (Durkheim ([1879] 1951), it is almost perceived as an unspoken but rather intended and expected rule that the group places on the individual. The sense of being and belonging that the individual places upon himself therefore becomes weak as the ideology of what he places upon himself strengthens, engulfing the individual and placing a stronger value for his sense of existence. To differentiate, the egoist for instance, while feeling unhappy, depressed, and dissatisfied with his/her life and thus resorting to suicide, the altruist, on the contrary has hope, determination and strong belief and attachment to the cause and is therefore willing to sacrifice his life for the afterlife. 
It is also imperative to note that Durkheim reveals in his examination of suicide, that altruistic suicide is more common in non-Western societies, because in Western societies "as individual personality becomes increasingly free from the collective personality, such suicides could not be widespread" (1979:228). The military, according to Durkheim, is the exception to this in modern western nations.

Suicide among the Palestinians is somewhat similar to suicide among war soldiers, in that they are both altruistic While the former is strongly bonded to an ideology that argues for the establishment of a State independent of oppression and suppression, the latter is socially bonded to a group set out for the defense of his own State (Leenaars \& Wenckstern 2004; Stack 2004). In both instances, there is a feeling of responsibility to serve the group and protect it from intruders and the enemy. Furthermore, while suicide bombers are perhaps in control of the time of execution, the solider is in an indeterminate state of execution. However, both have voluntarily submitted to a sovereign authority in exchange for the cause, where the cause to the dead is just.

Furthermore, since an independent Palestinian State is not established and is in a state of demarcation, it gives rise to an absence of a normally established order. This transitional stage of the already established order (the State of Israel) and the newly emerging order (the Palestinian State yet to be established) creates what Durkheim refers to as a state of anomie. In the next section, we analyze data consisting of suicide attacks that occurred between 1994 and 2008 to determine if the attacks during this time period have elements of the altruistic and anomic type.

\section{Statistical Analysis of the Suicide Bombings}

\subsection{Data}

In this research study, we examined suicide bombings that have occurred in the Palestinian/Israeli territories from April 1994 to February 2008. Specifically, we explored the characteristics that affect the likelihood that an attack occurred during the Second Intifada or occurred outside the time of the Second Intifada, by obtaining data on suicide attacks that cover over ten years of the Palestinian/Israeli conflict from the RAND Database of Worldwide Terrorism Incidents (RAND Database, 2012). Using the RAND Database of Worldwide Terrorism Incidents (WTI), we selected a sample of belt bombing attacks that reached their intended targets in Israel and the Palestinian territories. The attacks used in our sample contained the date of the suicide bombing, the number of people that were killed in the attack, the number of people that were injured in the attack, their group affiliation (Hamas, Palestine Islamic Jihad, Popular Front for the Liberation of Palestine, etc.), and a brief description of the attack. We restricted our data to suicide belt bombings to minimize the effect of potential uncontrollable variables in our analysis. For example, suicide belt bombers are less likely to be identified and stopped from carrying out their attacks.

Additionally, the data were augmented with information from the Chicago Project on Suicide Terrorism (CPOST) database (CPOST Database, 2012). Specifically, the information obtained from the WTI database was cross referenced with the CPOST database to obtain the age, income group, and gender of the bomber if this information was not revealed in the description of the attack provided by the WTI database. Subsequently, our data consisted of 82 belt bombing attacks that included the age of the attacker, income level of the attacker, the gender of the attacker, group affiliation, as well as the number of causalities and injuries inflicted by the attack. In addition, we considered the density of a suicide attack, as defined in Lafree et al (2009), to account for further variation in our data. The density of the attack is meant to account for any possible changes or actions taken by the perpetrators as a reaction to a failed attack.

We acknowledge that there are many characteristics, such as education, religiosity, nationalist motives, prior activity in terrorist organizations, and other social and religious characteristics, that may contribute to explaining differences between attacks that occurred during the Second Intifada and those outside that time period. However, there is a lack of informative characteristics about terror attacks due to the nature of terrorism (LaFree \& Dugan, 2007), and therefore there was a limitation on the data available. Brief descriptions of the variables considered in this study, along with the variable abbreviations, are provided in Table 1. Table 2 displays the first quartile, median, mean, and the third quartile of the quantitative data, as well as the frequency counts for our observed qualitative data. The perpetrators in our data sample had a known group affiliation, and this suggest the perpetrators may be considered as the altruistic type (Parrish, 2010). Using the data in the next section, we will examine if the suicide attacks considered in our study also possess elements of the anomic type. 
Table 1. Description of variables for the Terrorism data

\begin{tabular}{ll}
\hline phase & Attack occurred during the Second Intifada: $1=$ yes, $0=$ no \\
\hline killed & Number of people that were killed in the attack \\
\hline injuries & Number of people that were injured in the attack \\
\hline age & Age of the suicide bomber \\
\hline density & $\begin{array}{l}\text { The number of days covered by the three most recent attacks (including the } \\
\text { current attack) }\end{array}$ \\
\hline day & Day of the month that the bombing occurred \\
\hline income & $\begin{array}{l}\text { Income level group of the suicide bomber: } 0=\text { higher income, } 1=\text { lower income. } \\
\text { This variable was derived based on their employment classification (higher } \\
\text { income if a suicide bomber had skilled or professional employment, lower } \\
\text { income if a suicide bomber was unemployed or had unskilled employment) }\end{array}$ \\
\hline gender & Month of the year that the bombing occurred \\
\hline
\end{tabular}

Table 2. Numerical summaries for the Terrorism data

\begin{tabular}{lllll}
\hline & $1^{\text {st }}$ quartile & Median & Mean & 3rd quartile \\
\hline killed & 2.00 & 5.00 & 8.11 & 12.00 \\
injuries & 11.25 & 29.50 & 39.65 & 50.00 \\
age & 19.00 & 21.00 & 22.16 & 24.00 \\
density & 28.00 & 60.50 & 169.50 & 151.20 \\
day & 9.00 & 18.00 & 16.76 & 25.00 \\
month & 3.00 & 5.00 & 5.71 & 8.00 \\
\hline & Frequency count & & & \\
\hline phase & $0: 15 \quad 1: 67$ & & & \\
income & $0: 51 \quad 1: 31$ & & & \\
gender & $0: 7 \quad 1: 75$ & & & \\
\hline
\end{tabular}

\subsection{Methods}

We examine the effect of the independent variables in our study on the likelihood that a suicide attack occurred during the Second Intifada or outside this time period. The dependent variable in our study, denoted by phase $e_{i}$, is coded as 1 if the $i^{\text {th }}$ suicide belt bombing occurred during the Second Intifada and 0 if ith suicide attack did not occur during the Second Intifada. The following characteristics of the ith suicide attack constitute our independent variables: age of the bomber $\left(a g e_{i}\right)$ income group of the bomber (income $)_{i}$ ), gender of the bomber $\left(\right.$ gender $\left._{i}\right)$, day $\left(\right.$ day $\left._{i}\right)$, of the attack, month $\left(\right.$ month $\left._{i}\right)$ of the attack, the density of the attack $\left(\right.$ density $\left._{i}\right)$, and the number of fatalities $\left(\right.$ killed $\left._{i}\right)$ and injuries $\left(\right.$ injuries $\left._{i}\right)$ inflicted. We assume that the dependent variable, phasei, follows a Binomial distribution with one trial with the probability $\left(\pi_{\mathrm{i}}\right)$ that an attack occurred during the Second Intifada. We use logistic regression to study the likelihood that a suicide bombing occurred in the Second Intifada through the modeling of $z_{\mathrm{i}}=\log \left(\pi_{\mathrm{i}} /\left(1-\pi_{\mathrm{i}}\right)\right)$, which is the $\log$ odds of $\pi_{\mathrm{i}}$ attack occurring in the Second Intifada. A logistic regression model examines how zi is linearly related to a linear combination of a set of independent variables (Venables \& Ripley, 2003).

In regards to our data sample, income level was the only variable that was missing observations. However, we assume that the missing data are Missing at Random (MAR) as defined in Little and Rubin (1987). This assumption is reasonable since an attack occurring during the Second Intifada or outside this time period does not affect the missingness of this data. Missingness refers to the manner in which data are missing from a sample of a population. To account for the missing data, we used a nonparametric bootstrap to impute missing values 
and estimate the model parameters as described in Efron (1994). Since the missing data are MAR, a nonparametric bootstrap approach will account for variability in the estimated model parameters due to imputed values.

To determine which variables influence the likelihood that an attack took place during the Second Intifada, we built our model using a forward model selection procedure (Kutner et al, 2004) with a likelihood ratio test (McCullagh \& Nelder, 1989) at significance level 0.05 when the candidate models were nested and did not include the income level. When a candidate model included the income level of an attacker, we used bootstrap bias-corrected and accelerated (BCa) confidence intervals (Efron \& Tibshirani 1994; Efron 1994) at significance level 0.05 to determine the significance of the variables. The Akaike's information criterion (Eubank, 1999) was employed when candidate models were non-nested.

After taking into account all the aforementioned variables, and using our model selection criteria and diagnostics, the chosen logistic regression model to represent $z_{\mathrm{i}}$ is of the form

$$
z_{i}=\beta_{0}+\beta_{1} \text { gender }_{i}+\beta_{2} \text { injuries }_{i}+\beta_{3} \text { income }_{i}+\beta_{4}\left(\text { income }_{i}\right)\left(\text { injuries }_{i}\right)
$$

The age of the bomber $\left(a g e_{i}\right)$, density of the attack $\left(\right.$ density $\left._{i}\right)$, day $\left(\right.$ day $\left._{i}\right)$ of the attack, month $\left(\right.$ month $\left._{i}\right)$ of the attack, and the number of fatalities $\left(\right.$ killed $\left._{i}\right)$ inflicted did not significantly affect the likelihood that an attack took place during the Second Intifada. The income group of the bomber (income $)_{i}$, gender of the bomber $\left(\right.$ gender $\left._{i}\right)$, and the injuries (injuries $)_{i}$ ) inflicted were significant. The bootstrap estimated model coefficients $\left(b_{i}\right)$, standard errors (SE), 95\% BCa confidence intervals (CIs) for the estimated regression coefficients, and the exponentiated coefficients (OR) are given in Table 3. The methods used, as well as bootstrap parameter estimates obtained using 25,000 independent bootstrap samples, were implemented in R (R Development Core Team, 2011). In the next section, we interpret the estimated model components.

Table 3. Model summary

\begin{tabular}{llllll}
\hline $\begin{array}{l}\text { Independent } \\
\text { Variables }\end{array}$ & $\begin{array}{l}\text { Regression } \\
\text { Coefficients }\end{array}$ & $b_{i}$ & $\mathrm{SE}$ & $95 \% \mathrm{BCa}$ Cis & OR \\
\hline & $\beta_{0}$ & 20.406 & 1.893 & & \\
gender $_{i}$ & $\beta_{1}$ & -17.745 & 1.465 & $(-26.590,-16.290)$ & $<.001$ \\
injuries $_{i}$ & $\beta_{2}$ & -0.011 & 0.027 & $(-0.035,0.018)$ & 0.989 \\
income $_{i}$ & $\beta_{3}$ & -0.970 & 1.680 & $(-4.084,1.793)$ & 0.379 \\
(gender $\left._{i}\right)\left(\right.$ (ncome $\left._{i}\right)$ & $\beta_{4}$ & -0.066 & 0.054 & $(-0.288,-0.003)$ & 0.963 \\
\hline
\end{tabular}

\subsection{Results}

We interpret any estimated model coefficient when holding the other variables in our model constant. The effect of gender shows that the likelihood that an attack took place during the Second Intifada only slightly increases if the suicide bomber was male. The effect of income level and the number of injuries is analyzed through the significant interaction between these two variables. For an attacker in the higher income group, the odds of the attack being carried out during the Second Intifada decrease as the number injuries in an attack increase. Specifically, the odds decrease by $98.89 \%$ with each additional injury in an attack. For attackers in the lower income group, the odds of the attack being carried out in Second Intifada decrease by $92.56 \%$ with each additional injury in an attack. Therefore, an attacker was more likely to be part of the lower income group than the higher income group during the Second Intifada. Perpetrators in the lower income group may be viewed as the anomic type (Stack, 1982). This suggests that attacks during the Second Intifada were more likely to have elements of the anomic type. In addition, the greater the amount of injuries, the greater the odds that the attack was carried during the Second Intifada by an attacker in the lower income group rather than in the higher income group. That is, more deadly attacks during the Second Intifada were more likely to have elements of the anomic type.

Overall, using data that covers the Palestinian/Israeli conflict, we analyzed characteristics that affected the likelihood of a suicide attack by a Palestinian suicide bomber. Only gender, income level, and the number of injuries were significantly associated with the suicide bombing incidents considered in our study. 


\section{Conclusion}

We examined the individual psychological dynamics of Palestinian suicide bombers and their motivations to committing suicide attacks from social, economic, and political pressures. The research study specifically used a theoretical framework to build upon Durkheim's typologies of suicide, with an emphasis on the anomic and altruistic types. Using suicide bombing data obtained from the WTI and CPOST databases that cover the Palestinian/Israeli conflict from April 1994 to February 2008, we found that suicide belt bombings during this time period contained elements of the altruistic and anomic types of suicide. Specifically, all most all suicide bombers had a group affiliation, thereby possessing some elements of the altruistic type of suicide. However, attacks during the Second Intifada were more likely to possess elements of the anomic type of suicide since the perpetrators were more likely to have a lower income during the Second Intifada. In addition, we found that the suicide bombings during the Second Intifada were less deadly, in terms of injuries, but the extent of the devastation was dependent on the attacker's income level.

While in recent research the acts of suicide bombings have been largely attributed to the Palestinians, and more specifically to the religion of Islam, various cultures and religions have witnessed it over the past hundreds of years. For example, so-called suicide terrorism has occurred among the Jewish Sicaris, Asians, Moslem Hashishiyun, Sri Lanka, Turkey as well as more recently in Lebanon, Iraq and Egypt (Pedahzur et al 2003; Schweitzer 2001).

In general, the Middle Eastern region has been stereotyped by images of violence, terror, and suicide bombings. What the media has failed to note, however, is a more comprehensive comparative view of what is taking place in our current society and what has taken place centuries ago. So while suicide bombings in the Middle East have been portrayed as bizarre, thus producing a negative image associated specifically with Islam and the Arabs in general (Beyler 2003), it is historically evident that other bloody terrorist events have taken place in various regions across the world, indicating the sociopolitical nature of suicide terrorism utilized by powerless groups. The Palestinians' case is only one among many

\section{Acknowledgments}

We thank the editor and the reviewers for helpful comments and suggestions.

\section{References}

Abadie, A. (2006). Poverty, Political Freedom and the Roots of Terrorism. The American Economic Review 96(2), 50-56. http://dx.doi.org/10.1257/000282806777211847

Abdel-Khalek, A. M. (2004). Neither altruistic suicide, nor terrorism but martyrdom: A Muslim perspective. Archives of Suicide Research, 8(1), 99-113. http://dx.doi.org/10.1080/13811110490243840

Anderson, C. A., Gentile, D. A., \& Buckley, K. E. (2007). Violent video game effects on children and adolescents: Theory, research and public policy. http://dx.doi.org/10.1093/acprof:oso/9780195309836.001.0001

Atran, S. (2003). Genesis of suicide terrorism. Science, 299, 1534-1539. http://dx.doi.org/10.1126/science.1078854

Benmelech, E., Berrebi, C., \& Klor, E. F. (2012). Economic conditions and the quality of suicide terrorism. The Journal of Politics, 74(01), 113-128. http://dx.doi.org/10.1017/S0022381611001101

Beyler, C. (2005). Women Weapons. The New York Sun (June29). Accessed 17 September 2005, pp. 1-3.

Bloom, M. (2005). Dying to Kill: The Global Phenomenon of Suicide Terror. New York: Columbia University Press.

Brym, R. J., \& Araj, B. (2006). Suicide bombing as strategy and interaction: The case of the second intifada. Social Forces, 84(4), 1969-1986. http://dx.doi.org/10.1353/sof.2006.0081

Caldararo, N. (2006). Suicide bombers, terror, history, and religion. Anthropological Quarterly, 79(1), 123-131. http://dx.doi.org/10.1353/anq.2006.0003

CPOST Database. (n.d.). Suicide Attack Database. Chicago Project on Security and Terrorism. Retrieved September 12, 2012 from http://cpost.uchicago.edu/search.php

De Mesquita, E. B. (2005a). The quality of terror. American Journal of Political Science, 49(3), 515-530. http://dx.doi.org/10.1111/j.1540-5907.2005.00139.x

Dickey, C., Hosenball, M., \& Johnson, S. (2001). Training for Terror. Newsweek, 42.

Durkheim, E. (1951). Suicide. Glencoe. Understanding suicidal behaviour: The suicidal process approach to 
research and treatment.

Durkheim, E. (1979). Suicide: A Study in Sociology. G. Simpson (Ed.), J. A. Spaulding and G. Simpson (transl.). New York: The Free Press.

Efron, B. (1994). Missing data, imputation, and the bootstrap. Journal of the American Statistical Association, 89(426), 463-475. http://dx.doi.org/10.1080/01621459.1994.10476768

Efron, B., \& Tibshirani, R. J. (1994). An introduction to the bootstrap. CRC press.

Eubank, R. L. (1999). Nonparametric regression and spline smoothing. CRC press.

Fischer, S., Alonso-Gamo, P., \& Von Allmen, U. E. (2001). Economic developments in the West Bank and Gaza since Oslo. Economic Journal, F254-F275. http://dx.doi.org/10.1111/1468-0297.00629

Friedland,N. (1992). Becoming a terrorist: Social and individual antecedents. In L. Howard (Eds.), Terrorism: Roots, impact, responses. New York: Praeger.

Ganor, B. (2000). Suicide Terrorism: An Overview. In Countering Suicide Terrorism, Erzlia: ICT 134-45.

Gurr, T. R. (1970). Why Men Rebel. Princeton University Press.

Hassan, N. (2001). An Arsenal of Believers. Talking to the Human Bombs. New Yorker.

Hoffman, B. (1998). Inside Terorism. New York: Columbia University Press. Quoted in Laura Marlowe, "A Fiery Cleric's Defense of Jihad," Time, 15 January 1996.

Israeli Ministry of Defense. (2005).

Johnson, K. K. (1979). Durkheim revisited:“Why do women kill themselves?”. Suicide and Life-Threatening Behavior, 9(3), 145-153.

Kadman, N. (2012). Employment of Palestinians in Israel and the Settlements Restrictive Policies and Abuse of Rights. Kav La Oved.

Khawaja, M. (1995). The dynamics of local collective action in the West Bank: A test of rival explanations. Economic Development and Cultural Change, 44(1), 147-179. http://dx.doi.org/10.1086/452204

Krueger, A. B., \& Laitin, D. D. (2008). Kto kogo?: A cross-country study of the origins and targets of terrorism. $\begin{array}{lllll}\text { Terrorism, economic development, and political openness, } & \text { 148-173. }\end{array}$ http://dx.doi.org/10.1017/CBO9780511754388.006

LaFree, G., \& Dugan, L. (2007). Introducing the global terrorism database. Terrorism and Political Violence, 19(2), 181-204. http://dx.doi.org/10.1080/09546550701246817

LaFree, G., Dugan, L., \& Korte, R. (2009). The impact of british counterterrorist strategies on political violence in northern ireland: comparing deterrence and backlash models. Criminology, 47(1), 17-45. http://dx.doi.org/10.1111/j.1745-9125.2009.00138.x

Le Bon, G. (1969)[1895]. The Crowd: A Study of the Popular Mind. Ballantine Books.

Leenaars, A. A., \& Wenckstern, S. (2004). Altruistic suicides: are they the same or different from other suicides? Archives of Suicide Research, 8(1), 131-136. http://dx.doi.org/10.1080/13811110490243831

Legal Consequences of Israel's Construction of a Separation Barrier in the Occupied Territories International Law Opinion by Oxford Public Interest Lawyers (OXPIL) for the Association for Civil Rights in Israel (ACRI) University of Oxford.

Little, R. J., \& Rubin, D. B. (2014). Statistical analysis with missing data. John Wiley \& Sons.

McCullagh, P., \& Nelder, J. A. (1989). Generalized linear models (2nd ed.). Chapman and Hall/CRC. http://dx.doi.org/10.1007/978-1-4899-3242-6

Merari, A. (1998). The readiness to kill and die: Suicidal terrorism in the Middle East. In W. Reich (Ed.), Origins of terrorism: Psychologies, ideologies, theologies, states of mind (pp. 192-207). Washington, D.C.: Woodrow Wilson Center Press.

Merari, A. (2005). Suicide Terrorism. In R. I.Yufit \& D. Lester (Eds.), Assessment, treatment and prevention of suicidal behaviour. New York: John Wiley \& Sons.

Moghadam, A. (2003). Palestinian suicide terrorism in the second intifada: Motivations and organizational aspects. Studies in conflict and terrorism, 26(2), 65-92. http://dx.doi.org/10.1080/10576100390145215

Moore, D. (2003). Perceptions of sense of control, relative deprivation, and expectations of young Jews and 
Palestinians in Israel. The Journal of social psychology, 143(4), 521-540. http://dx.doi.org/10.1080/00224540309598460

Munir, M. (2008). Suicide attacks and Islamic law. International Review of the Red Cross, 90(869). http://dx.doi.org/10.1017/S1816383108000040

Nachtsheim, C. J., Neter, J., Kutner, M. H., \& Wasserman, W. (2004). Applied linear regression models. McGraw-Hill Irwin.

Nonnemaker, J. M., McNeely, C. A., \& Blum, R. W. (2003). Public and private domains of religiosity and adolescent health risk behaviors: evidence from the National Longitudinal Study of Adolescent Health. Social science \& medicine, 57(11), 2049-2054. http://dx.doi.org/10.1016/S0277-9536(03)00096-0

Orbach, I. (2004). Terror Suice: How is it Possible? Archives of Suicide Research, 8, 115-130. http://dx.doi.org/10.1080/138111104902343787

Pape, R. A. (2003). The Strategic Logic of Suicide Terrorism. American Political Science Review, 97, 343-361. http://dx.doi.org/10.1017/S000305540300073X

Pape, R. A. (2005). Dying to Win: The Strategic Logic of Suicide Terrorism. New York: Random House.

Parrish, M. (2010). Social work perspectives on human behaviour. Berkshire, ENG: Open University Press

Paz, R. (2000). The Islamic legitimacy of suicide terrorism. Countering Suicide Terrorism, 96-97.

Paz, R. (n.d.). The Islamic Legitimacy of Suicide Terrorism. p. 93.

Pedahzur, A., Perliger, A., \& Weinberg, L. (2003). Altruism and fatalism: The characteristics of Palestinian suicide terrorists. Deviant Behavior, 24(4), 405-423. http://dx.doi.org/10.1080/713840227

Poland, J. M. (2003). Suicide bombers: A global problem. Humboldt Journal of Social Relations, 100-135.

Post, J., Sprinzak, E., \& Denny, L. (2003). The terrorists in their own words: Interviews with 35 incarcerated Middle Eastern terrorists. Terrorism and political Violence, 15(1), 171-184. http://dx.doi.org/10.1080/09546550312331293007

Quoted in Laura Marlowe. “A Fiery Cleric's Defense of Jihad.” Time, 15 January 1996. See Bruce Hoffman, Inside Terrorism (New York: Columbia University Press, 1998), p. 97.

R Development Core Team. (2011). R: A Language and Environment for Statistical Computing. R Foundation for Statistical Computing. Vienna, Austria.

RAND Database. (n.d.). Database of Worldwide Terrorism Incidents. The RAND Corporation. Retrieved September 12, 2012 from http://smapp.rand.org/rwtid/search_form.php

Reich, W. (Ed.). (1990). Origins of Terrorism. Cambridge University Press.

Rosenberger, J. (2003). Discerning the behavior of the suicide bomber: The role of vengeance. Journal of Religion and Health, 42, 13-20. http://dx.doi.org/10.1023/A:1022208626691

Roy, S. (2001). Decline and disfigurement: The Palestinian economy after Oslo. In R. Cary (Ed.), the new intifada: Resisting Israel's apartheid (pp. 91-109). New York: Verso.

Schweitzer, Y. (2001). Suicide Bombings: The Ultimate Weapon?. The Institute for Counter-Terrorism.

Spaulding, J., \& Simpson, G. (1979) Emile Durkheim. Suicide: A Study in Sociology. Edited with an introduction by George Simpson. Translated by John A. Spaulding \& George Simpson.

Sprinzak, E. (2000). Rational fanatics. Foreign Policy, (120), 66-73. http://dx.doi.org/10.2307/1149715

Stack, S. (1982). Suicide: A decade review of the sociological literature. Deviant Behavior, 4(1), 41-66. http://dx.doi.org/10.1080/01639625.1982.9967602

Stack, S. (2004). Emile Durkheim and Altruistic Suicide. Archives of Suicide Research, 8, 9-22. http://dx.doi.org/10.1080/13811110490243741

Taylor, M., \& Ryan, H. (1988). Fanaticism, political suicide and terrorism. Terrorism, 11, 91-111. http://dx.doi.org/10.1080/10576108808435703

Townsend, E. (2007). Suicide Terrorists: Are They Suicidal?. Suicide \& Life-Threatening Behavior 37. http://dx.doi.org/10.1521/suli.2007.37.1.35

Venables, W. N., \& Ripley, B. D. (2003). Modern Applied Statistics with S. Springer, Fourth Edition. 
Williams, J. M. G. (1997). Suicide and attempted suicide. London:Penguin.

Young, L. C. (1972). Altruistic Suicide: A Subjective Approach. Sociological Bulletin, 21(2), 103-21.

\section{Copyrights}

Copyright for this article is retained by the author(s), with first publication rights granted to the journal.

This is an open-access article distributed under the terms and conditions of the Creative Commons Attribution license (http://creativecommons.org/licenses/by/3.0/). 